\title{
Seed size-number trade-off in Euterpe edulis in plant communities of the Atlantic
}

\section{Forest}

\author{
Pedro Henrique Santin Brancalion ${ }^{1 *}$, Ricardo Ribeiro Rodrigues ${ }^{2}$
}

\author{
'University of São Paulo/ESALQ - Dept. of Forest Sciences, \\ C.P. 09 - 13418-900 - Piracicaba, SP - Brazil. \\ ${ }^{2}$ University of São Paulo/ESALQ - Dept. of Biological \\ Sciences. \\ *Corresponding author <pedrob@usp.br>
}

Edited by: Daniel Scherer de Moura

Received August 28, 2013

Accepted December 20, 2013

\begin{abstract}
Investigations of seed size and number differences among plant populations growing in contrasting habitats can provide relevant information about ecological strategies that optimize reproductive effort. This may imply important consequences for biodiversity conservation and restoration. Therefore, we sought to investigate seed size-number trade-off in Euterpe edulis populations growing in plant communities in the Brazilian Atlantic Forest. Seed dry mass and seed number per bunch were evaluated in 2008 and 2009 in large remnants of the Seasonally Dry Forest, Restinga Forest and Atlantic Rainforest in southeastern Brazil, in 20 individuals per site and year. Seed size and seed number varied among forest types, but a seed size-number tradeoff was neither observed within nor among populations. Positive association between seed size and number was found in the Atlantic Rainforest, and reduced seed crop was not accompanied by heavier seeds in the Restinga Forest. Seed dry mass declined in 2009 in all three forest types. Compared to seed number in 2008, palms of both the Restinga Forest and the Atlantic Rainforest produced in 2009 higher yields of smaller seeds - evidence of between years seed size-number trade-off -, while the Seasonally Dry Forest population produced a reduced number of smaller seeds. Such a flexible reproductive strategy, involving neutral, positive, and negative associations between seed size and number could enhance the ecological amplitude of this species and their potential to adapt to different environment conditions.
\end{abstract}

Keywords: seed ecology, seed dispersal, seed size optimization, plant reproductive effort, seedling establishment

\section{Introduction}

Seed size has been considered an important functional trait that determines the occurrence and distribution of plant species in ecological communities (Moles et al., 2005; Ben-Hur et al., 2012). Community composition can be influenced by this trait as a result of dispersal limitation processes, since the capacity of propagule movement in the landscape through wind or vertebrate dispersers is affected by seed size (Fenner and Thompson, 2005), and by seedling establishment limitation processes, since seed mass may determine seedling fitness under different water, light and nutrient conditions (Leishman and Westoby, 1994; Bond et al., 1999; Seiwa, 1998).

Seed size may also be a key functional trait in the assessment of human-mediated disturbances in plant communities. For instance, Galetti et al. (2013) showed that the functional extinction of large-bodied frugivorous birds in the Atlantic Forest resulted in the reduction of seed size, due to the selection being mediated by smallgaped birds, of the Euterpe edulis palm in defaunated remnants. Additionally, seed size can influence the vulnerability of recalcitrant-seeded species to climate change, because smaller seeds may be more exposed to desiccation during the abnormal drought periods recently observed in tropical and temperate forests (Galetti et al., 2013; Joët et al., 2013). Thus, the ability of plant species to regulate seed size in different plant communities and under divergent environmental conditions may determine their capacity to overcome new ecological filters imposed by human-mediated disturbances and, consequently, to persist in native ecosystems.

One of the key processes regulating seed mass is the optimization of plant reproductive efforts through a seed size-number trade-off (Venable, 1992; Paul-Victor and Turnbull, 2009). Trade-offs in seed size and number are important for plant survival in different habitats, as this association may be critical to mother plant fitness in response to divergent or changing environmental conditions (Gilbert et al., 2006; Muller-Landau, 2010). However, to date, there are only a few studies that describe seed sizenumber trade-offs in woody species (Venable, 1992), and the studies available are not conclusive (Vaughton and Ramsey, 1998; Parciak, 2002; Koenig et al., 2009).

The investigation of seed size-number trade-off in populations of the endangered palm Euterpe edulis is worth considering because the variations of its seed size may affect its potential to adapt to defaunation and to persist in native ecosystems under climate change scenarios projected for the Atlantic Forest (Lopes, 2013; Galetti et al., 2013). Therefore, we sought to investigate seed size-number trade-off in Euterpe edulis populations growing in different plant communities of the Brazilian Atlantic Forest.

\section{Materials and Methods}

\section{Study sites and species}

This research was carried out at the neotropical 
Atlantic Forest biome Hotspot (located mostly on the Brazilian eastern coast), which is both extremely endangered and exceptionally important for biodiversity conservation because of its high diversity of species and high levels of endemism (Laurance, 2009). In this highly critical situation Euterpe edulis is considered by some researchers as a keystone species for frugivores, since its fruits are consumed by at least 30 bird and 15 mammal species in periods of food scarcity (Fadini et al., 2009), although its keystone role has not been demonstrated to date (Galetti and Aleixo, 1998). E. edulis fruit is a globular drupe with a very thin mesocarp enclosing a single seed, so that seed size determines fruit width and pulp/ seed ratio remain invariant to seed size (Queiroz, 2000).

E. edulis is a single-stemmed understory palm (5-20 $\mathrm{m}$ tall) endemic to the Atlantic Forest biome, where it occurs predominantly in soils with high water availability (Brancalion et al., 2012). Its edible 'heart of palm' is the most important non-timber forest product exploited in the Atlantic Forest and, as a result of overexploitation, this species is at risk of extinction (Reis et al., 2000).

We studied E. edulis populations in the Restinga Forest (RF - Parque Estadual da Ilha do Cardoso,
Cananéia-SP), the Atlantic Rainforest (AR - Parque Estadual de Carlos Botelho, Sete Barras-SP) and the Seasonally Dry Forest (SDF - Estação Ecológica dos Caetetus, Gália-SP) (Table 1). We concentrated our studies on populations found in 10.24-ha permanent plots established within representative portions of each forest type protected in the Natural Reserves of São Paulo State, SE Brazil, where E. edulis is the most abundant species in the areas of RF and AR under study

\section{Evaluation of seed size and seed crop}

Seeds were harvested from $20 \mathrm{E}$. edulis individuals from each study site in May 2008 and in May 2009. Although this species produces ripe fruits for up to six months, we chose to harvest seeds in May because only in this month did we find an abundant yield of ripe fruits in all the three forest types under study, that would allow further comparison of seed size and crop variation among populations in the same period. Different individuals from those sampled in 2008, but as close as possible to them, were harvested in 2009. Seed harvesting was carried out inside the forests, maintaining a minimum distance of $50 \mathrm{~m}$ between mother palms.

Table 1 - Main biotic and abiotic characteristics of the forest types where seed size and number were studied in Euterpe edulis populations (data obtained from 256 plots with $20 \times 20$ m from 10.24-ha Permanent Plots located in each forest type - Programa Biota, 2006).

\begin{tabular}{llll}
\hline \multirow{2}{*}{ Biotic and abiotic characteristics } & Forest types & \\
\cline { 2 - 3 } & Atlantic Rainforest & Restinga Forest & Seasonally Dry Forest
\end{tabular}

Study sites

Topography

Predominant soil
Parque Estadual de Carlos Botelho $\left(37,793\right.$ ha $-24^{\circ} 00^{\prime}-24^{\circ} 15^{\prime} S$ and

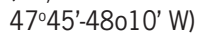

Equatorial climate (Af), mean temperature $=21.8^{\circ} \mathrm{C}$ and annual rainfall $=$ $1,582 \mathrm{~mm}$, without dry season.

Mountainous (average altitude $=400$ m)

Cambisol: clay (45\% sand, $17 \%$ silt, $38 \%$ clay), low nutrient status ( $P=$ $3.5 \mathrm{mg} \mathrm{kg}^{-1}, \mathrm{~K}=1.9 \mathrm{mmol} \mathrm{kg}^{-1}, \mathrm{Ca}$ $=3.8 \mathrm{mmol}_{\mathrm{c}} \mathrm{kg}^{-1}, \mathrm{Mg}=3.2 \mathrm{mmol}$ $\left.\mathrm{kg}^{-1}\right)$ and low $\mathrm{pH}\left(\mathrm{pH}_{0.01 \mathrm{M} \mathrm{CaC12}}=3.8\right)$ and high aluminum content $(\mathrm{Al}=20$ $\mathrm{mmol}_{\mathrm{c}} \mathrm{kg}^{-1}$ )

Floristic richness (perimeter at breast height - pbh > $15 \mathrm{~cm}$ )

205 species and 44 families

Floristic similarity with the other Permanent Parcels

$14 \%$ with RF and $11 \%$ with SDF

$21 \%$ of total individuals ( $1^{\text {th }}$ most

E. edulis abundance $(\mathrm{pbh}>15 \mathrm{~cm})$

Pbh (> $15 \mathrm{~cm}, X \pm D P$ ) of $E$. edulis abundant species - 240 individuals ha-1)

$10.3 \pm 4 \mathrm{~cm}, N=2,307$
Parque Estadual da llha do Cardoso $\left(22,500\right.$ ha $-25^{\circ} 03^{\prime} 05^{\prime \prime}-25^{\circ} 18^{\prime} 18^{\prime \prime} \mathrm{S}$ and $47^{\circ} 53^{\prime} 48^{\prime \prime}-48^{\circ} 05^{\prime} 42^{\prime \prime} \mathrm{W}$ )

Equatorial climate (Af), with strong influence of oceanity, mean temperature $=22.4^{\circ} \mathrm{C}$ and annual rainfall $=$ $2,261 \mathrm{~mm}$, without dry season.

Coastal-flat, next to sea level (average altitude $=7 \mathrm{~m}$ )

Ferrocarbic Spodosol: hydromorfic, sandy (90\% sand, $4 \%$ silt, $6 \%$ clay), low nutrient status $\left(P=3.3 \mathrm{mg} \mathrm{kg}^{-1}\right.$, $\mathrm{K}=0.8 \mathrm{mmol}_{\mathrm{c}} \mathrm{kg}^{-1}, \mathrm{Ca}=1.9 \mathrm{mmol}_{c}$ $\mathrm{kg}^{-1}, \mathrm{Mg}=3.0 \mathrm{mmol}^{-1} \mathrm{~kg}^{-1}$, low $\mathrm{pH}$ $\left(\mathrm{pH}_{0.01 \mathrm{M} \mathrm{CaCl2}}=3.0\right)$ and high aluminum content $\left(\left.A\right|^{\prime}=9.4 \mathrm{mmol} \mathrm{kg}^{-1}\right)$

114 species and 43 families

$5 \%$ with SDF and $14 \%$ with AR

$20 \%$ of total individuals ( $1^{\text {th }}$ most abundant species - 300 individuals ha $^{-1}$ )

$7.4 \pm 2 \mathrm{~cm}, N=3,076$
Estação Ecológica dos Caetetus $\left(2,178 \mathrm{ha}-22^{\circ} 46^{\prime} \mathrm{S}\right.$ and $\left.49^{\circ} 16^{\prime} \mathrm{W}\right)$

Humid sub-tropical climate (Cwa), with dry season in the winter (water deficit $=10 \mathrm{~mm}$ ), mean temperature $=21.4$ ${ }^{\circ} \mathrm{C}$ and annual rainfall $=1,303 \mathrm{~mm}$.

Flat to slightly mountainous (average altitude $=522 \mathrm{~m}$ )

Ultisol: well-drained, sandy clay loam (78 \% sand, $10 \%$ silt, $12 \%$ clay), high nutient status $\left(P=4.9 \mathrm{mg} \mathrm{kg}^{-1}\right.$, $\mathrm{K}=3.1 \mathrm{mmol}_{\mathrm{c}} \mathrm{kg}^{-1}, \mathrm{Ca}=38.7 \mathrm{mmol}_{\mathrm{c}}$ $\left.\mathrm{kg}^{-1}, \mathrm{Mg}=8.5 \mathrm{mmol}_{\mathrm{c}} \mathrm{kg}^{-1}\right)$ and moderate $\mathrm{pH}\left(\mathrm{pH}_{0.01 \mathrm{MCaCl}}=5.1\right)$ and almost nule aluminum content

148 species and 44 families

$5 \%$ with RF and $11 \%$ with AR

$0.1 \%$ of total individuals $\left(65^{\text {th }}\right.$ most abundant species - 1.3 individuals ha $^{-1}$ )

$9.92 \pm 3 \mathrm{~cm}, N=100$ 
Only bunches bearing ripe fruits were harvested, from which all the seeds were collected for the evaluations. The dbh of all mother palms was measured in 2009. Pulp was removed from E. edulis fruits by placing them on a wire-mesh screen and rinsing abundantly in running water. Fruits were then processed separately for each bunch, avoiding mixing seeds from different mother palms and provenances. Individual seed dry mass (oven method $-105 \pm 3{ }^{\circ} \mathrm{C}$ for $24 \mathrm{~h}$; two replicates of 20 seeds) and seed crop per bunch were evaluated for each palm. Daily precipitation data for the period of seed development were obtained from the cities close to the areas under study, i.e., Alvinlândia-SP for SDF - 10 $\mathrm{km}$ from the study area; and Iguape-SP for RF - $24 \mathrm{~km}$ from the study area, and AR - $60 \mathrm{~km}$ from the study area (see geographic coordinates in Table 1).

\section{Data analysis}

Based on the seed number and size evaluated per individual, in natural populations growing in the three forest types, and for two consecutive years, we sought to test the following hypotheses: (H1) seed size is negatively correlated with seed number production by each individual within populations; (H2) seed size is negatively correlated with seed number production among different forest types; (H3) seed size and number are negatively correlated as regards response to betweenyear changes in seed production. We then used Pearson's correlations to evaluate the correlations among seed dry mass $\left(\log _{10}\right.$ transformed data), seed crop per bunch $\left(\log _{10}\right.$ transformed data), bunch number per palm, and palm stem diameter for each forest type and year (H1).

A two-factor ANOVA was applied to seed dry mass $\left(\log _{10}\right.$ transformed data) and seed crop per bunch data $\left(\log _{10}\right.$ transformed data) considering forest types and years as random factors. Palm dbh was initially inserted in the model as a covariate in ANCOVA to analyze data from 2009, but dbh data were not inserted in the model because their effect on the dependent variable was not significant.

Tukey's test $(p<0.05)$ was employed for multiple comparisons among means to compare seed size and number among forest types, and non-paired $t$ tests were used to compare seed yield and number between years, in each forest type. One observation from SDF in 2009 was removed from the analysis because it was considered an outlier.

\section{Results}

\section{Seed size and crop variation within populations}

Seed dry mass was highly variable among individuals, ranging from 0.35 to $1.81 \mathrm{~g}$ per seed (Figure 1), while seed yield ranged from 48 to 3,216 seeds per bunch. There was no correlation $(p<0.05)$, in either year, between bunch number, seed crop, and seed dry mass within populations, except for the positive association between seed dry mass and seed number per bunch in the AR population in 2009 (Table 2). Thus, no seed size-number trade-off was observed at the population level. These variables showed no correlation with stem diameter within populations (Table 2).

\section{Seed size and crop variation among populations}

No seed size-number trade-off was observed among forest types in either year. In 2008, the reduced number of seeds produced by the RF population was not accompanied by any increase in seed mass (Table 3). In addition, AR palms produced in 2009 a higher yield of bigger seeds as compared with the SDF population evidence of a positive association between seed size and number, and no trade-off (Table 3). Again, the reduced crop of seeds produced by the RF population in 2009 was not followed by an increase in seed size as compared with the AR population (Table 3).

\section{Seed size and crop variation between years}

Seed dry mass declined in 2009 in all three forest types. Compared to seed yield in 2008, palms in both the RF and the AR produced larger crops of smaller seeds in 2009 - evidence of between years seed sizenumber trade-off. However, SDF palms produced a reduced crop of smaller seeds in this same year (Table 4). The accumulated rainfall in the final period of seed development was lower in 2009, as compared with 2008, in the SDF, but much higher in the RF and AR (Table 5).

\section{Discussion}

The range of seed size found in this study $(0.35$ to $1.81 \mathrm{~g}, 517 \%$ ) was much higher than that reported in previous studies $(8.3$ to $14.1 \mathrm{~mm}, 170 \%$ - Pizo et

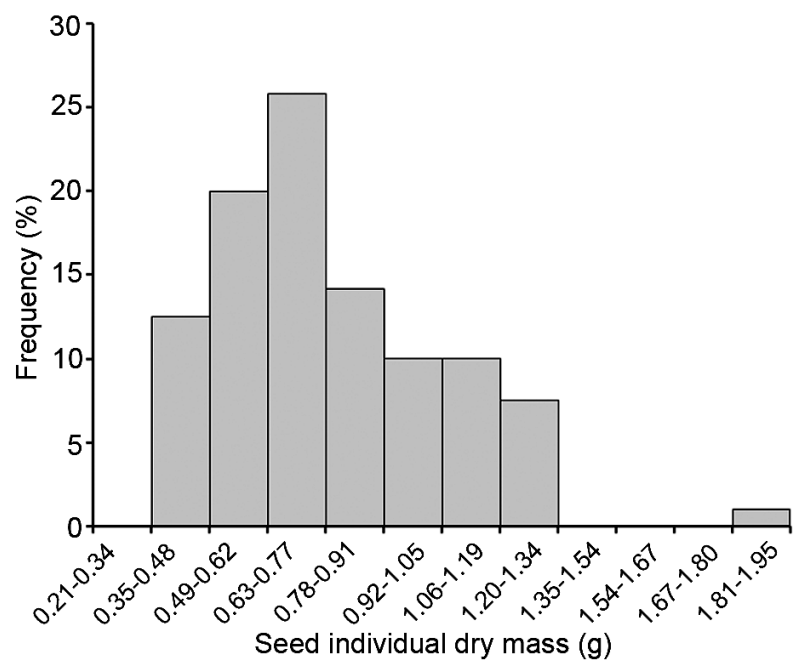

Figure 1 - Frequency distribution of Euterpe edulis individual seed mass. Each value in the graph represents the mean individual seed dry mass of each of the 120 individuals sampled in forest types from the Atlantic Forest biome of southeastern Brazil. 
Table 2 - Pearson's correlations among Euterpe edulis palm seed dry mass, seed number per bunch, bunch number per palm, and perimeter at breast height (PBH) in each year and forest types, all of them included in the Brazilian Atlantic Forest from Southeastern Brazil. Seeds were collected from 20 individuals per forest type per year.

\begin{tabular}{|c|c|c|c|}
\hline Forest type and year & Independent variables & $r$ & $p^{\dagger}$ \\
\hline \multicolumn{4}{|c|}{ a) Dependent variable $=$ seed dry mass } \\
\hline \multicolumn{4}{|l|}{ Atlantic Rainforest } \\
\hline \multirow[t]{2}{*}{2008} & seed number per bunch & -0.26 & 0.27 \\
\hline & bunch number per palm & -0.12 & 0.10 \\
\hline \multirow[t]{3}{*}{2009} & seed number per bunch & 0.51 & 0.02 \\
\hline & bunch number per palm & 0.02 & 0.99 \\
\hline & PBH & 0.28 & 0.91 \\
\hline \multicolumn{4}{|l|}{ Restinga Forest } \\
\hline \multirow[t]{2}{*}{2008} & seed number per bunch & -0.24 & 0.31 \\
\hline & bunch number per palm & -0.39 & 0.09 \\
\hline \multirow[t]{3}{*}{2009} & seed number per bunch & -0.29 & 0.22 \\
\hline & bunch number per palm & 0.42 & 0.06 \\
\hline & PBH & -0.26 & 0.26 \\
\hline \multicolumn{4}{|l|}{ Seasonally Dry Forest } \\
\hline \multirow[t]{2}{*}{2008} & seed number per bunch & -0.20 & 0.40 \\
\hline & bunch number per palm & 0.35 & 0.13 \\
\hline \multirow[t]{3}{*}{2009} & seed number per bunch & 0.17 & 0.48 \\
\hline & bunch number per palm & 0.22 & 0.33 \\
\hline & PBH & 0.14 & 0.56 \\
\hline \multicolumn{4}{|c|}{ b) Dependent variable $=$ seed number per bunch } \\
\hline \multicolumn{4}{|l|}{ Atlantic Rainforest } \\
\hline 2008 & bunch number per palm & -0.12 & 0.61 \\
\hline \multirow[t]{2}{*}{2009} & bunch number per palm & 0.67 & 0.78 \\
\hline & PBH & 0.23 & 0.32 \\
\hline \multicolumn{4}{|l|}{ Restinga Forest } \\
\hline 2008 & bunch number per palm & -0.10 & 0.67 \\
\hline \multirow[t]{2}{*}{2009} & bunch number per palm & 0.48 & 0.84 \\
\hline & $\mathrm{PBH}$ & 0.40 & 0.08 \\
\hline \multicolumn{4}{|l|}{ Seasonally Dry Forest } \\
\hline 2008 & bunch number per palm & -0.09 & 0.71 \\
\hline \multirow[t]{2}{*}{2009} & bunch number per palm & 0.23 & 0.33 \\
\hline & $\mathrm{PBH}$ & 0.08 & 0.74 \\
\hline
\end{tabular}

${ }^{\dagger}$ Significant test results $(p<0.05)$ are indicated in boldface letters.

Table 3 - Effects of Atlantic Forest biome forest types on seed dry mass, seed number per bunch, and bunch number per palm for Euterpe edulis in 2008 and 2009.

\begin{tabular}{lcccc}
\hline Forest type & Year & $\begin{array}{c}\text { Seed dry mass } \\
(\mathrm{g})^{\dagger}\end{array}$ & Seeds/bunch ${ }^{\dagger}$ & Bunches/plant $^{\dagger}$ \\
\hline Atlantic Rainforest & 2008 & $0.88 \mathrm{~A}$ & $977 \mathrm{~A}$ & $2.23 \mathrm{~A}$ \\
Restinga Forest & & $0.87 \mathrm{~A}$ & $245 \mathrm{~B}$ & $1.05 \mathrm{~B}$ \\
Seasonally Dry & & $1.06 \mathrm{~A}$ & $1147 \mathrm{~A}$ & $2.00 \mathrm{~A}$ \\
Forest & & & & \\
& & & & \\
Atlantic Rainforest & 2009 & $0.67 \mathrm{~A}$ & $1610 \mathrm{~A}$ & $2.45 \mathrm{~A}$ \\
Restinga Forest & & $0.63 \mathrm{AB}$ & $476 \mathrm{~B}$ & $1.35 \mathrm{~B}$ \\
Seasonally Dry & & $0.55 \mathrm{~B}$ & $757 \mathrm{~B}$ & $1.83 \mathrm{~B}$ \\
Forest & & &
\end{tabular}

${ }^{\dagger}$ Means followed by the same letter in the column, within each year, did not differ by Tukey's test $(p<0.05)$.
Table 4 - Effects of year in Euterpe edulis seed dry mass and seed number per bunch within different forest types from the Atlantic Forest biome of southeastern Brazil.

\begin{tabular}{lccccc}
\hline $\begin{array}{l}\text { Study sites and } \\
\text { dependent variable }\end{array}$ & \multicolumn{2}{c}{ Mean } & $t$ & df & $p^{\dagger}$ \\
\hline $\begin{array}{l}\text { a) Atlantic Rainforest } \\
\text { seed dry mass (g) }\end{array}$ & 0.88 & 0.69 & 3.11 & 1.38 & $\mathbf{0 . 0 0 3 5}$ \\
seeds/bunch & 969 & 1610 & -3.77 & 1.38 & $\mathbf{0 . 0 0 0 5}$ \\
& & & & & \\
b) Restinga Forest & & & & & \\
seed dry mass (g) & 0.89 & 0.63 & 4.02 & 1.38 & $\mathbf{0 . 0 0 0 3}$ \\
seeds/bunch & 252 & 476 & -3.73 & 1.38 & $\mathbf{0 . 0 0 0 6}$ \\
& & & & & \\
c) Seasonally Dry Forest & & & & & \\
seed dry mass (g) & 1.04 & 0.55 & 8.14 & 1.38 & $<\mathbf{0 . 0 0 0 1}$ \\
seeds/bunch & 1193 & 757 & 2.45 & 1.38 & 0.01876 \\
\hline TSignificant test results $(p<0.05)$ are indicated in boldface letters.
\end{tabular}

Table 5 - Between-year variation in accumulated rainfall 30, 60 and 90 days before Euterpe edulis seed harvesting dates in different forest types from the Atlantic Forest biome of Southeastern Brazil.

\begin{tabular}{lcccc}
\hline \multirow{2}{*}{ Forest type } & \multicolumn{4}{c}{$\begin{array}{c}\text { Accumulated rainfall before seed harvesting } \\
\text { (mm) }\end{array}$} \\
\cline { 3 - 5 } & & 90 days & 60 days & 30 days \\
\hline $\begin{array}{l}\text { Restinga Forest and } \\
\text { Atlantic Rainforest }\end{array}$ & 2008 & 390 & 279 & 78 \\
& 2009 & 837 & 502 & 162 \\
Seasonally Dry & 2008 & 451 & 243 & 90 \\
Forest & 2009 & 379 & 101 & 30 \\
\hline
\end{tabular}

al., 2006; 6.3 to $14.6 \mathrm{~mm}, 232 \%$ - Galetti et al., 1999), giving evidence that the amplitude of seed size variation in this species may be much wider than expected. This result was remarkably influenced by a single individual sampled in the Seasonally Dry Forest that produced seeds with mean individual dry mass of $1.81 \mathrm{~g}$. If this value is removed from the dataset, the range of seed size is closer, but still higher, than those studies (0.35 to $1.35 \mathrm{~g}$, $385 \%)$. This highlights the importance of large sample sizes when assessing seed mass in E. edulis wild populations.

The absence of a significant association between seed size and number within the populations under study indicates that negative or positive correlations between these variables were not a general response of each individual to its specific maternal environment conditions, as has already been observed in other species (Koenig et al., 2009). On the one hand, negative associations between seed crop and size may be observed when unfavorable environmental conditions in the initial seed development phases result in the abortion of immature fruits, thus reducing seed crop per bunch, but subsequent favorable maternal environment promotes seed filling and increased individual seed mass (an example of a negative association between seed crop and 
mass - smaller crop of bigger seeds). On the other hand, positive associations may be observed when mother plants face very favorable maternal environmental conditions throughout the seed development process, which provides enough resources for keeping a high number of fruits in the bunch, since immature fruits are not aborted, and for filling seeds with higher contents of photoassimilate (an example of a positive association between seed crop and mass - larger crop of bigger seeds).

Furthermore, dbh did not affect seed size or seed number in any population, so that clearly these variables may vary independently even in similar-sized plants, possibly as a result of the different levels of availability of resources like water, light, nutrients, and pollinators. However, a positive association between seed size and number may occur in some isolated cases, as was observed in AR in 2009. Indeed, as discussed by Venable (1992), neutral or positive associations between seed size and number may be the result of modular plant growth, in which individual plants may have substantial differences in the amount of resources available to them for seed production.

Positive association between seed size and number also occurred when these variables were compared between populations, which may have been enhanced by genetic divergences. This was observed when the AR population produced larger crops of heavier seeds than did the SDF population in 2009. This indicates possibly, that the greater the amount of resources available for reproduction, the higher the investment in seed mass and seed crop. Consequently, a simple and direct positive association between plant resource status and seed number was expected (Cheplick and Sung, 1998; Paul-Victor and Turnbull, 2009). Indeed, E. edulis occurred in much higher density at the permanent plot of the AR under study than in the SDF (Table 1), so that more favorable conditions for reproduction may be found at the former forest type (Brancalion et al., 2012). In contrast, in a study carried out in a temperate environment, Parciak (2002) observed that the fleshy-fruited small tree Prunus virginiana produced a higher crop of smaller seeds in a moist riparian habitat than in dry slope habitats, which suggests that negative associations between seed size and number may enhance fitness in different habitats, because bigger seeds promote seedling establishment in drier habitats.

A seed-size number trade-off was observed in $E$. edulis populations in RF and AR between 2008 and 2009, indicating that such response to interannual variations in maternal environment may occur to optimize mother palm reproductive effort. This may be the result of a remarkably higher precipitation in the final stages of seed development in these forest types in 2009, which apparently encouraged the production of a higher crop of smaller seeds.

In summary, we found no conclusive evidence of seed size-number trade-off in E. edulis. Indeed, positive, neutral and negative associations between seed size and number can be observed provided that the study evaluates these associations within populations in a given year, within a given population in different years, or even among habitats. Therefore, the associations between seed size and number may be a simple and direct consequence of the combination of genetic differences among individuals with variations in plant resource status in space and time. On the one hand, natural selection may determine overtime optimal ranges of seed size and number for each species. On the other, variations in seed size and number may not be a strategy for optimizing mother plant reproductive efforts in woody species in each reproductive period, as can be observed in herbs (Venable, 1992).

The lack of a pattern of association between seed size and number can also be a consequence of the limitations of the experiment, where uncontrolled field conditions may have hampered a more precise evaluation of this association. Given that most of the studies showing a seed size-number trade-off in plants were carried out with herbaceous species in controlled environments (Venable, 1992), field experiments with long-lived plants may indeed have a poor "resolution" for assessing this reproductive strategy. Nevertheless, studies on seed size-number trade-off in trees and palms are highly important for many reasons and deserve further attention from researchers.

Some strategies recommended for minimizing the undesirable effects of uncontrolled field conditions in this kind of work are: i) evaluating the same individual in different years; ii) evaluating specific microsite conditions where each individual is growing; iii) evaluating similar sized individuals; iv) manipulating environmental factors with techniques such as soil fertilization, irrigation and thinning for better understanding how a given individual may shift its reproductive strategy; vi) evaluating genetic divergence among individuals. These are general recommendations for improving seed size-number trade-off assessments of long-lived plants, but ideally seed crop and size should be monitored throughout the whole life of the individual - not only for a single or a few fructification events -, which is still a relevant constraint for understanding mother plant reproductive effort regulation in palms and trees.

\section{Acknowledgments}

Pedro H. S. Brancalion thanks FAPESP (São Paulo State Foundation for Research Support) for financial support (07/53088-1) and Projeto Parcelas Permanentes/ BIOTA/FAPESP (99/09635-0) for field research support. Ricardo R. Rodrigues thanks CNPq (Brazilian National Council for Scientific and Technological Development) for financial support. We thank Prof. José M. Gómez and Prof. Felipe Ribeiro for his thorough comments on a preliminary version of the manuscript and Dr. James Aronson and Alaine Ball for English review and helpful comments on several subsequent versions of the manuscript. 


\section{References}

Ben-Hur, E.; Fragman-Sapir, O.; Hadas, R.; Singer, A.; Kadmonet, R. 2012. Functional trade-offs increase species diversity in experimental plant communities. Ecology Letters 15: 12761282.

Bond, W.J.; Honig, M.; Maze, K.E. 1999. Seed size and seedling emergence: an allometric relationship and some ecological implications. Oecologia 120: 132-136.

Brancalion, P.H.S.; Vidal, E.; Lavorenti, N.A.; Batista, J.L.F.; Rodrigues, R.R. 2012. Soil-mediated effects on potential Euterpe edulis (Arecaceae) fruit and palm heart sustainable management in the Brazilian Atlantic Forest. Forest Ecology and Management 284: 78-85.

Cheplick, G.P.; Sung, L.Y. 1998. Effects of maternal nutrient environment and maturation position on seed heteromorphism, germination and seedling growth in Triplasis purpurea (Poaceae). International Journal of Plant Science 159: 338-350.

Fadini, R.F.; Fleury, M.; Donatti, C.A.; Galetti, M. 2009. Effects of frugivore impoverishment and seed predators on the recruitment of a keystone palm. Acta Oecologica 35: 188-196.

Fenner, M.; Thompson, K. 2005. The Ecology of Seeds. Cambridge University Press, Cambridge, UK.

Galetti, M.; Aleixo, A. 1998. Effects of palm heart harvesting on avian frugivores in the Atlantic rain forest of Brazil. Journal of Applied Ecology 35: 286-293.

Galetti, M.; Zipparro, V.B.; Morellato, L.P.C. 1999. Fruiting phenology and frugivory on the palm Euterpe edulis in a lowland atlantic forest of Brazil. Ecotropica 5: 115-122.

Galetti, M.; Guevara, R.; Côrtes, M.C.; Fadini, R.; VonMatter, S.; Leite, A.B.; Labecca, F.; Ribeiro, T.; Carvalho, C.S.; Collevatti, R.G.; Pires, M.M.; Guimarães Jr, P.R.; Brancalion, P.H.S.; Ribeiro, M.C.; Jordano, P. 2013. Functional extinction of birds drives rapid evolutionary changes in seed size. Science 340 : 1086-1090.

Gilbert, B.; Wright, S.J.; Muller-Landau, H.C.; Kitajima, K.; Hernandéz, A. 2006. Life history trade-offs in tropical trees and lianas. Ecology 87: 1281-1288.

Joët, T.; Ourcival, J.; Dussert, S. 2013. Ecological significance of seed desiccation sensitivity in Quercus ilex. Annals of Botany 111: 693-701.

Koenig, W.D.; Knops, J.M.H.; Carmen, W.J.; Sage, R.D. 2009. No trade-off between seed size and number in the Valley Oak Quercus lobata. The American Naturalist 173: 682-688.

Laurance, W.F. 2009. Conserving the hottest of the hotspots. Biological Conservation 142: 1137.

Leishman, M.R.; Westoby, M. 1994. The role of large seeds in seedling establishment in dry soil conditions: experimental evidence for semi-arid species. Journal of Ecology 82: 249-258.
Lopes, N. 2013. Geographic distribution of Atlantic Rainforest trees could decrease $65 \%$ by $2100=$ Distribuição geográfica de árvores da Mata Atlântica pode cair 65 \% até 2100. Revista FAPESP. Available at: http://agencia.fapesp.br/en/17879 [Accessed 26/08/2013].

Moles, A.T.; Ackerly, D.D.; Webb, C.O.; Tweddle, J.C.; Dickie, J.B.; Westoby, M. 2005. A brief story of seed size. Science 307: 576-580.

Muller-Landau, M.C. 2010. The tolerance-fecundity trade-off and the maintenance of diversity in seed size. Proceedings of the National Academy of Sciences of the USA 107: 4242-4247.

Paul-Victor, C.; Turnbull, L. 2009. The effect of growth conditions on the seed size/number trade-off. PLoS One 4: e6917.

Parciak, W. 2002. Environmental variation in seed number, size, and dispersal of a fleshy-fruited plant. Ecology 83: 780-793.

Pizo, M.A.; von Allmen, C.; Morellato, L.P.C. 2006. Seed size variation in the palm Euterpe edulis and the effects of seed predators on germination and seedling survival. Acta Oecologica 29: 311-315.

Programa Biota. 2006. IV Relatório Temático do Projeto Parcelas Permanentes. Available at: http://www.lerf.esalq.usp.br/old/ parcelas/relatorio2005/introducao.pdf [Accessed 14/12/2011]

Queiroz, M.H. 2000. Biology of the fruit, seed and germination of palmiteiro Euterpe edulis Martius-Arecacea = Biologia do fruto, da semente e da germinação do palmiteiro Euterpe edulis Martius-Arecaceae. p. 39-59. In: Reis, M.S.; Reis, A., eds. Euterpe edulis Martius (Palmiteiro): biology, conservation and management $=$ Euterpe edulis Martius (Palmiteiro): biologia, conservação e manejo. Herbário Barbosa Rodrigues, Itajaí, SC, Brazil (in Portuguese).

Reis, M.S.; Fantini, A.C.; Nodari, R.O.; Reis, A.; Guerra, M.P.; Mantovani, A. 2000. Management and conservation of natural populations in Atlantic Rain Forest: the case study of palm heart (Euterpe edulis Martius). Biotropica 32: 894-902.

Seiwa, K. 1998. Advantages of early germination for growth and survival of seedlings of Acer mono under different overstore phenologies in deciduous broad-leaved forests. Journal of Ecology 86: 219-228.

Vaughton, G.; Ramsey, M. 1998. Sources and consequences of seed mass variation in Banksia marginata (Proteaceae). Journal of Ecology 86: 563-573.

Venable, D.L. 1992. Size-number trade-offs and the variation of seed size with plant resource status. American Naturalist 140: 287-304. 